\title{
ГЕНЕТИЧНА СТРУКТУРА ЗА ОВОПРОТЁ̈НОВИМИ ЛОКУСАМИ В ПРОЦЕСІ СТВОРЕННЯ ДИМОРФНОЇ ПОПУЛЯЦІЇ ГУСЕЙ
}

\author{
Бондаренко Юрій Васильович \\ доктор біологічних наук, професор \\ Сумський національний аграрний університет \\ ORCID: 0000-0002-5746-379X \\ E-mail: yuvbond@ukr.net
}

Хвостик Віктор Павлович

доктор сільськогосподарських наук Інститут розведення і генетики тварин імені М.В. Зубця НАAH

ORCID: 0000-0002-8107-4831

E-mail: lab29@meta.ua

Роботу проведено в умовах племінного заводу ДППП «Роздольне» Харківської області з розведення гусей великої сірої та рейнської порід. Внаслідок проведення прямих і зворотних схрещувань птииі иих порід виведено гусей диморфрної популяиії з подвійною аутосексністю - в добовому і статевозрілому віці. Проведено дослідження генетичної структури за поліморффними локусами яєчного білку гусей вихідних батьківських форм, нащадків першого-третього поколінь та створеної диморффної популяції. Після електрофорезу в крохмальному гелі фрракційний склад овопротеїнів розподілявся на такі інтенсивно забарвлені зони: овоальбуміну (OV), овомукоїду (OM), трансфрерину (TF), овомакроглобуліну (OMG). У дослідної птиці локуси OV, TF та OMG виявилися мономорфьними - усі особини мали гомозиготний фенотип AA, тому частота алеля *А в кожному з цих локусів дорівнювала 1,000. Значні відмінності між дослідженими групами гусей встановлено за локусом овомукоїду ОМ, який виявився сильно поліморфьним і представленим трьохалельною кодомінантною системою * $А$, *B, ${ }^{*} \mathrm{C}$. Відмінності, передусім, пов'язані з характером розподілу фенотипів та ступенем співпадання фрактичної і теоретично очікуваної їх кількості. У всіх досліджених групах птиці основу популяційного генофонду складали носії переважно алеля $О \mathrm{M}^{*}$ в в гомо- чи гетерозиготному стані. При цьому гетерозиготних особин $А В$ фактично виявлено менше, а гомозиготних AA - більше, ніж теоретично очікувалося. У локусі, який детермінує поліморфізм овомукоїду, частота більш поширеного алеля *А у гусей досліджених груп знаходилася в межах 0,531-0,750. Слід відмітити, що вірогідних відмінностей за частотою алелей у цьому локусі між гусьми досліджених популяцій не досягнуто. За рівнем гетерозиготності вірогідної різниці між дослідженими групами птиці не встановлено. Найменший показник гетерозиготності визначено увеликих сірих гусей $(7,19 \%)$, у рейнських дещо більше - 12,19\%. У гусей першого покоління рівень гетерозиготності займає проміжне положення $(11,56 \%)$ поміж вихідними батьківськими породами. У гусей $F_{2}-F_{3}$ та диморфрної популяиії рівень гетерозиготності підвищується до 13,75-15,00\%.

Ключові слова: гуси, схрещування, локус, яєчний білок, генетична структура, гетерозиготність.

DOI: https://doi.org/10.32845/bsnau.lvst.2020.3.4

При створенні нових селекційно-значимих форм сільськогосподарської птиці вітчизняної селекції актуальним і важливим постає питання виявлення реальної спрямованості генетичних процесів у ході селекційного процесу [1]. Молекулярно-генетичні маркери дають змогу виявляти породоспецифічні характеристики генетичних структур вихідних батьківських форм та нащадків ряду поколінь. Ї з успіхом можна застосовувати в селекційній роботі для пошуку та створення унікальних генотипів, проводити контроль мікроеволюційних процесів у популяціях за впливу різних методів розведення [2].

Широко застосовують спадково обумовлені маркерні ознаки у птахівництві при створенні нових селекційних форм. Так, зокрема, встановлено, що гібридні кури характеризувалися вищою частотою алелей ${ }^{*} A$ локусу $G(3)$ та ${ }^{*} B$ локусу $G(2)$, ніж батьківські форми. За рівнем гетерозиготності птиця вихідних родинних форм не суттєво відрізнялася поміж собою $(16,38 \%$ та $18,38 \%)$, тоді як гібриди займали проміжне положення за цим показником - 16,67\% [3].

Подстрєшна І. О. із співавт. [4] виявили різницю між вихідними формами і гібридами за частотою алелей поліморфних локусів яєчного білка. Частота алелей у гібридів мала

проміжне значення з наближенням до однієї з батьківських форм. За маркерними ознаками нащадки більшою мірою подібні між собою, ніж з вихідними родинними формами.

Остапенко В. І. [5] проведено порівняльний аналіз міжпородних відмінностей курей за електрофоретичними типами білків. Між вивченими породами птиці спостерігалася генетична дивергенція, частіше за все пов'язана з різною частотою одних і тих самих алелей овопротеїнових локусів. Генофондд обстежених порід курей за частотою окремих алелей відрізняється залежно від напряму продуктивності.

Метою роботи було дослідити генетичну структуру за протеїновими локусами яєчного білка гусей вихідних батьківських форм, нащадків першого-третього поколінь та виведеної диморфної популяції.

Матеріали та методи досліджень. Дослідження проведено на базі ДППП «Роздольне» Харківської області. Як вихідні батьківські форми при виведенні гусей диморфної популяції використано птицю рейнської та великої сірої порід, за прямого та зворотного схрещувань якої отримано нащадків ряду поколінь [6]. Розподіл протеїнів яєчного білку гусей на генетично обумовлені фракції проводили за використання вертикального електрофорезу у крохмальному гелі за Smithies

Вісник Сумського національного аграрного університету Серія «Тваринництво», випуск 3 (42), 2020 
O. [7] з використанням буферних систем Gahne B. [8] у відповідності до методики [9]. Визначення типів поліморфних білків здійснювали у відповідності до загальноприйнятої схеми [10] з доповненнями [11]. Рівень гетерозиготності (\%) оцінювали як відношення загальної кількості усіх гетерозигот у даній вибірці певної групи птиці до загального числа обстежених локусів.

Результати досліджень. Досліджено генетичну структуру за протеїновими локусами яєчного білка птиці вихідних батьківських форм, нащадків першого-третього поколінь та диморфної популяції. Дослідження проведено за чотирма локусами, які контролюють синтез найбільш важливих протеїнів білка яєць. Після електрофорезу в крохмальному гелі фракційний склад овопротеїнів розподілявся на такі інтенсивно забарвлені зони: овоальбуміну (OV), овомукоїду (OM), трансферину (TF), овомакроглобуліну (OMG).

У дослідної птиці локуси OV, TF та OMG виявилися мономорфними - усі особини мали гомозиготний фенотип $\mathrm{AA}$, тому частота алеля * $A$ в кожному з цих локусів дорівнювала 1,000. Мономорфрізм цих локусів виявлено й в інших дослідженнях $[12,13]$.
Значні відмінності між дослідженими групами гусей встановлено за локусом овомукоїду ОМ, який виявився сильно поліморфним і представленим трьохалельною кодомінантною системою * $A$, " $B$, * $C$, здатною внаслідок комбінаторики генів утворювати 6 дискретних фенотипів - АА, ВВ, СС, AB, AC, BC. Ці відмінності, передусім, пов'язані з характером розподілу фенотипів та ступенем співпадання фактичної і теоретично очікуваної їх кількості (табл. 1).

У гусей великої сірої породи в локусі овомукоїду частіше за інших траплялися гомозиготи АA, тоді як найменше гетерозиготи $\mathrm{AB}$. Доля останніх у рейнських гусей найбільша серед дослідженої птиці. Значною доля цих гетерозигот $(37,5-42,5 \%)$ була і у нащадків $F_{1}-F_{2}$ та створених диморфних гусей.

Досить рідкісний гетерозиготний варіант ВС з невисокою частотою 1,25 \% виявлено у птиці вихідної материнської форми, тоді як у рейнських гусей даної вибірки він був відсутній. У гібридів $\mathrm{F}_{1}$ доля трапляння цих гетерозигот зросла до $2,5 \%$, а у нащадків послідуючих поколінь вона ще більша - у межах 3,75-8,75\%.

Таблиця 1

Фактичний і теоретичний розподіл фенотипів

у локусі овомукоїду в досліджених групах гусей

\begin{tabular}{|c|c|c|c|c|c|c|c|c|}
\hline \multirow{2}{*}{$\begin{array}{c}\text { Порода, генерація, } \\
\text { популяція }\end{array}$} & \multirow{2}{*}{$\begin{array}{c}\text { Досліджено яєць, } \\
\text { шт. }\end{array}$} & \multirow{2}{*}{$\begin{array}{l}\text { Розподіл, } \\
\text { ФІТ }\end{array}$} & \multicolumn{6}{|c|}{ Фенотипи } \\
\hline & & & AA & $A B$ & BB & $\mathrm{BC}$ & $\mathrm{AC}$ & $x^{2}$ \\
\hline \multirow[t]{2}{*}{ Рейнська біла } & \multirow[t]{2}{*}{80} & $\Phi$ & 25,0 & 39,0 & 16,0 & 0,0 & 0,0 & \multirow[t]{2}{*}{0,01} \\
\hline & & $T$ & 24,7 & 39,5 & 15,8 & 0,0 & 0,0 & \\
\hline \multirow[t]{2}{*}{ Велика сіра } & \multirow[t]{2}{*}{80} & $\Phi$ & 49,0 & 22,0 & 8,0 & 1,0 & 0,0 & \multirow[t]{2}{*}{7,69} \\
\hline & & $T$ & 45,0 & 29,3 & 4,8 & 0,2 & 0,7 & \\
\hline \multirow[t]{2}{*}{$\mathrm{F}_{1}$} & \multirow[t]{2}{*}{80} & $\Phi$ & 35,0 & 34,0 & 8,0 & 2,0 & 1,0 & \multirow[t]{2}{*}{1,56} \\
\hline & & $\mathrm{T}$ & 34,4 & 34,1 & 8,5 & 1,0 & 2,0 & \\
\hline \multirow[t]{2}{*}{$\mathrm{F}_{2}$} & \multirow[t]{2}{*}{80} & $\Phi$ & 22,0 & 30,0 & 10,0 & 7,0 & 11,0 & \multirow[t]{2}{*}{0,28} \\
\hline & & $T$ & 22,6 & 30,2 & 10,1 & 6,4 & 9,6 & \\
\hline \multirow[t]{2}{*}{$\mathrm{F}_{3}$} & \multirow[t]{2}{*}{80} & $\Phi$ & 22,0 & 28,0 & 14,0 & 3,0 & 13,0 & \multirow[t]{2}{*}{5,05} \\
\hline & & $T$ & 22,6 & 31,3 & 10,9 & 5,9 & 8,5 & \\
\hline \multirow[t]{2}{*}{ Диморфна } & \multirow[t]{2}{*}{80} & $\Phi$ & 23,0 & 32,0 & 12,0 & 5,0 & 8,0 & \multirow[t]{2}{*}{0,18} \\
\hline & & $T$ & 23,2 & 32,8 & 11,6 & 5,0 & 7,0 & \\
\hline
\end{tabular}

Примітки: 1) в таблиці наведено фактичний і теоретичний розподіл фенотипів лище поліморфнного локусу яєчного білка, 2) $\Phi$ - фактично виявлена кількість фенотипів локусу, $T$ - теоретично розрахована кількість фенотипів локусу.

Гетерозиготний варіант АС у гусей вихідних батьківських порід знайдено не було. У гібридних гусей $\mathrm{F}_{1}$ лише одна особина мала даний фенотип, частота зустрічання якого склала $1,25 \%$. Проте, у нащадків $\mathrm{F}_{2}-\mathrm{F}_{3}$ та диморфних гусей доля трапляння цих гетерозигот значно підвищилася до 10,00-16,25 \% з найбільшим проявом у птиці третього покоління.

Отже, у всіх досліджених групах птиці основу популяційного генофонду складали носії переважно алеля $O M^{\star} A$ в гомо- чи гетерозиготному стані. При цьому гетерозиготних особин $A B$ фактично виявлено менше, а гомозиготних $A$ A більше, ніж теоретично очікувалося.

Більш значні відхилення між фактичним і теоретичним розподілом фенотипів встановлено у гусей великої сірої породи, що ледве не призвело до порушення у них генетичної рівноваги за цим локусом. Критерій відповідності $X^{2}$ в даній поліалельній поліморфній системі становив 7,69 й максимально наблизився до величини 7,8, після якої порушення генетичної рівноваги набуває вірогідного значення. Тоді як у гусей рейнської породи, які тривалий час розводяться в умовах па- нміксії, відмічено значну подібність фрактичного і теоретичного розподілу фенотипів, тому співвідношення генотипів даної групи гусей знаходиться в стані цілковитої генетичної рівноваги $\left(X^{2}=0,01\right)$.

У локусі, який детермінує поліморфізм овомукоїду, частота більш поширеного алеля * $A$ у гусей досліджених груп знаходилася в межах 0,531-0,750 (табл. 2). Слід відмітити, що вірогідних відмінностей за частотою алелей у цьому локусі між гусьми досліджених популяцій не досягнуто.

У гусей великої сірої породи частота алеля $O M^{*} A \epsilon$ найбільшою $(0,750)$. Очевидно, що переважаюча концентрація гомозигот $\mathrm{Om}^{*} \mathrm{AA}$, яких, до речі, у них було більше на 30,0$33,75 \%$, ніж в іншої птиці, та значна кількість гетерозигот $A B$ $(27,5 \%)$ сприяли досягненню найвищого значення серед дослідженої птиці.

У гусей рейнської породи, нащадків $\mathrm{F}_{2}-\mathrm{F}_{3}$ та диморфної популяції частота більш поширеного алеля * $A$ суттєво не відрізнялася, що свідчить про незначну розбіжність розподілу фенотипів у них. 
Найбільшою частота алеля $O M^{*} B$ була у гусей рейнської породи, що обумовлено значною кількістю гомо- і гетерозиготних фенотипів за цим алелем. У потомків $\mathrm{F}_{1}-\mathrm{F}_{3}$ та диморфних гусей частота цього алеля подібна, що свідчить про несуттєву відмінність у співвідношенні гомо- і гетерозиготних фенотипів між цією птицею. Можна відзначити підвищення частоти даного алеля від нащадків $\mathrm{F}_{1}$ до диморфної популяції. До речі, у птиці $F_{1}$ частота алелей $A$ і В локусу овомукоїду займала проміжне положення поміж вихідними формами, на базі яких вони створені, але все ж більше наближалася до материнської породи (великих сірих гусей).

Частота алелей локусу овомукоїду та

Таблиця 2

рівень гетерозиготності у досліджених групах гусей

\begin{tabular}{|c|c|c|c|c|c|}
\hline \multirow{2}{*}{ Порода, генерація, популяція } & \multirow{2}{*}{$\mathrm{n}$} & \multicolumn{3}{|c|}{ Алелі } & \multirow{2}{*}{ Рівень гетерозиготності, \% } \\
\cline { 4 - 5 } & & ${ }^{*} A$ & ${ }^{*} B$ & ${ }^{*} \mathrm{C}$ & 12,19 \\
\hline Рейнська біла & 80 & 0,556 & 0,444 & 0,000 & 7,19 \\
\hline Велика сіра & 80 & 0,750 & 0,244 & 0,006 & 11,56 \\
\hline $\mathrm{F}_{1}$ & 80 & 0,656 & 0,325 & 0,019 & 15,00 \\
\hline $\mathrm{F}_{2}$ & 80 & 0,531 & 0,356 & 0,113 & 13,75 \\
\hline $\mathrm{F}_{3}$ & 80 & 0,531 & 0,369 & 0,100 & 14,06 \\
\hline Диморфна & 80 & 0,538 & 0,381 & 0,081 & \\
\hline
\end{tabular}

Примітки: 1) за локусами OV, TF, OMG всі групи гусей мономорфнні за алелем *А, тому частоти алелей в таблиці не наводяться; 2) рівень гетерозиготності розраховували за чотирма дослідженими локусами (OV, OM, TF, OMG).

У гусей великої сірої породи наявність серед обстеженого поголів'я однієї гетерозиготи ВС дало змогу встановити частоту алеля $O M^{*} C$ на рівні 0,006 . У нащадків $F_{1}$ вже виявляються дві гетерозиготи $\mathrm{BC}$ та одна $\mathrm{AC}$, що сприяє підвищенню частоти алеля до 0,019. У обстеженого поголів'я гусей рейнської породи не виявлено гомо-та гетерозиготних носіїв алеля * ${ }^{*}$. Виходячи з цих даних, можна припустити, що гуси $\mathrm{F}_{1}$ алель ${ }^{*} \mathrm{C}$ отримали саме від гусей великої сірої породи, яка виступала у якості материнської форми при їх створенні.

Дещо вищу частоту алеля *C засріксовано у потомків $\mathrm{F}_{2}-\mathrm{F}_{3}$, що стало результатом зростання долі трапляння у них гетерозиготних фенотипів $A C$ та BC. Й насправді, у гусей $F_{2}$, порівняно з іншою птицею, доля гетерозигот ВС була найбільшою (8,75 \%), а у птиці $F_{3}$ виявлено максимальну долю гетерозиготного варіанту АС. У диморфних гусей частота цього алеля склала 0,081 внаслідок наявності у локусі 10,00 \% гетерозигот AC та $6,25 \%$ гетерозигот BC.

За рівнем гетерозиготності вірогідної різниці між дослідженими групами птиці не встановлено. Найменший показник гетерозиготності визначено у великих сірих гусей $(7,19$ \%), що, можливо, передусім обумовлено досить тривалим розведенням цієї птиці „у собі” без застосування „прилиття крові” гусей вихідних батьківських порід, які приймали участь у її створенні, або „освіження крові” від великої сірої породи $з$ інших господарств.
У гусей рейнської породи, не дивлячись також на тривале замкнуте розведення „у собі” за умови панміксії, рівень гетерозиготності вищий $(12,19 \%)$, ніж у великих сірих. Це свідчить про відсутність тісного інбридингу при розведенні птиці та перспективність її використання у селекційних програмах.

У гусей першого покоління рівень гетерозиготності займає проміжне положення (11,56 \%) поміж вихідними батьківськими породами. Отримані дані співпадають з результатами досліджень інших авторів [14], які встановили також проміжний рівень гетерозиготності за протеїнами сироватки крові у гібридних гусей, отриманих від схрещування італійських з фрранцузькими.

У гусей $\mathrm{F}_{2}-\mathrm{F}_{3}$ та диморфної популяції рівень гетерозиготності підвищується до 13,75-15,00 \%, що можна пояснити їх високою гетерогенністю порівняно з іншою птицею, так як вони створені внаслідок міжпородного схрещування.

Величина генетичної відстані, розрахована на основі частоти алелей локусу овомукоїду, свідчить про найменші відмінності генетичної структури гусей третього покоління і диморфної популяції - $d=0,0003$ (табл. 3). Це можна пояснити тим, що диморфні гуси є прямими нащадками птиці $F_{3}$ і тому розподіл гомо-та гетерозиготних фенотипів у них набуває мінімальних розбіжностей.

Таблиця 3

Величина генетичної відстані між дослідженими групами гусей

\begin{tabular}{|c|c|c|c|c|c|}
\hline Порода, генерація, популяція & Рейнська біла & $\mathrm{F}_{1}$ & $\mathrm{~F}_{2}$ & $\mathrm{~F}_{3}$ & Диморфна \\
\hline Велика сіра & 0,1609 & 0,0720 & 0,1549 & 0,1554 & 0,0529 \\
\hline Рейнська біла & - & 0,0904 & 0,0839 & 0,0736 & 0,0089 \\
\hline $\mathrm{F}_{1}$ & & - & 0,0921 & 0,0897 & 0,0167 \\
\hline $\mathrm{F}_{2}$ & & & - & 0,0106 & 0,0015 \\
\hline $\mathrm{F}_{3}$ & & & & - & 0,0003 \\
\hline
\end{tabular}

На дендрограмі родинних взаємовідношень ця птиця об'єднується в один кластер з мінімальним значенням генетичної відстані. До них приєднуються гуси другого покоління та вихідної батьківської форми. Це свідчить про більшу подібність генетичної структури гусей рейнської породи до такої у птиці $F_{2}-F_{3}$, ніж до великих сірих та гібридів $F_{1}$. Можливо, це пов'язано з тим, що рейнські гуси неодноразово були задіяні до процесу створення диморфних гусей, що й призвело до схожості їх алелофонду.
Найбільш суттєві відмінності генетичної структури за овобілками визначено між гусьми великої сірої породи та рейнськими, нащадками $\mathrm{F}_{2}-\mathrm{F}_{3}$. Величина генетичної відстані між ними найбільша - в межах $d=0,1554-0,1609$. Це свідчить про специфічність алелофонду породної птиці, її генетичну унікальність.

Окремий кластер утворюють гуси великої сірої породи та їх нащадки першого покоління. Тобто, потомки $\mathrm{F}_{1}$ за генетичною структурою овобілків проявляють більшу подібність 
до вихідної материнської форми, ніж до батьківської. Варто зазначити, що подібну тенденцію відмічено нами раніше на курях у ході створення материнської форми нового яєчного кросу «Слобідський-2А» [15].

Висновки. Використання класичних біохімічних мар- керних ознак дало змогу визначити частоту алелей високополіморфного локусу овомукоїду, оцінити рівень гетерогенності та міжгрупової диференціації гусей вихідних батьківських форм, нащадків ряду поколінь у процесі виведення диморфної популяції.

\section{Список використаної літератури:}

1. Подстрєшний О. П. Генетична структура птиці в ході гібридизації. Птахівництво. 2005. Вип. 57. С. 107-113.

2. Маринчук Г. Е. Полиморфные системы лактопротеинов крупного рогатого скота как генные маркеры. ДнепропетроBCK, 2007. 260 c.

3. Катериннич О. О., Ткачик Т. Е., Руда С. В. Оцінка генетичної структури курей за поліморфними локусами білків яєць при гібридизації. Птахівниитво. 2010. Вип. 65. С. 52-57.

4. Подстрєшна І. О., Подстрєшний О. П., Катеринич О. О. Відтворення двох різновидів курей під генетичним контролем. Птахівниитво. 2010. Вип. 66. С. 244-252.

5. Остапенко В. І. Генетична структура порід і кросів птиці за поліморфрними системами білків яєць. Вісник аграрної науки Причорномор'я. 2011. Вип. 1 (158). С. 198-202.

6. Хвостик В. П. Обгрунтування та практична реалізація методичних підходів до створення нових і удосконалення існуючих популяцій сільськогосподарської птиці : авторефф. дис. ... докт. с.-г. наук : 06.02.01. с. Чубинське Київської області, 2015. $40 \mathrm{c}$.

7. Smithies O. Zone electrophoresis in starch gels and its application to studies serum protein. Advance Protein Chem. 1959. V. 14. P. 65-113.

8. Gahne B. Studies on the inheritance of electrophoresis forms of transferrins, albumins, pre-albumins and plasma esterases of horses. Genetics. 1966. V. 53, №4. P. 681-693.

9. Кутнюк П. И., Волохович В. А., Моисеева И. Г. Электрофоретический анализ белков сельскохозяйственной птицы: методические рекомендации. Харьков, 1986. 32 с.

10. Baker C., Croiser G., Stratil A. Identity and nomenclature of some protein polymorphism of chicken eggs and serum. Advan. Genet. 1970. V. 5, №2. P. 147-174.

11. Моисеева И. Г., Кутнюк П. И., Волохович В. А. Генетический анализ изменчивости белков сельскохозяйственной птицы: методические рекомендации. Харьков, 1985. 16 с.

12. Подстрєшний О. П., Наливайко Л. І., Бондаренко Ю. В. Генетичний поліморфізм в популяціях великих сірих гусей. Птахівництво. 2001. Вип. 50. С. 19-26.

13. Smalec E. M., Miszkiewicz J., Wojcik E. The protein polymorphism of different goose strains. Птахівництво. 2001. Вип. 51. C. $141-145$.

14. Сруога А., Янушонис С., Буткаускас Д. Генетические маркеры в исследовании диффференциации пород домашних гусей. Veterinarija ir zootechnika. 2002. Т. 20 (42). Р. 101 -106.

15. Хвостик В. П. Динаміка генетичної структури птиці при створенні нових та удосконаленні існуючих популяцій яєчних курей : автореф. дис. ... канд. с.-г. наук : 06.02.01. Харків, 2004. 20 с.

\section{References:}

1. Podstryeshnij O. P. Genetichna struktura ptici v hodi gibridizaciyi. Ptahivnictvo. 2005. issue 57. pp. 107-113.

2. Marinchuk G. E., 2007. Polimorfnye sistemy laktoproteinov krupnogo rogatogo skota kak gennye markery. Dnepropetrovsk, 260.

3. Katerinnich O. O., Tkachik T. E. and Ruda S. V., 2010. Ocinka genetichnoyi strukturi kurej za polimorfnimi lokusami bilkiv yayec pri gibridizaciyi. Ptahivnictvo. issue 65. pp. 52-57.

4. Podstryeshna I. O., Podstryeshnij O. P. and Katerinich O. O., 2010. Vidtvorennya dvoh riznovidiv kurej pid genetichnim kontrolem. Ptahivnictvo, issue 66, pp. 244-252.

5. Ostapenko V. I., 2011. Genetichna struktura porid i krosiv ptici za polimorfnimi sistemami bilkiv yayec. Visnik agrarnoyi nauki Prichornomor'ya, issue 1 (158), pp. 198-202.

6. Hvostik V. P., 2015. Obgruntuvannya ta praktichna realizaciya metodichnih pidhodiv do stvorennya novih i udoskonalennya isnuyuchih populyacij silskogospodarskoyi ptici : avtoref. dis. ... dokt. s.-g. nauk : 06.02.01. s. Chubinske Kiyivskoyi oblasti, 40.

7. Smithies O., 1959. Zone electrophoresis in starch gels and its application to studies serum protein. Advance Protein Chem., issue 14, pp. 65-113.

8. Gahne B., 1966. Studies on the inheritance of electrophoresis forms of transferrins, albumins, pre-albumins and plasma esterases of horses. Genetics, issue 53, no. 4, pp. 681-693.

9. Kutnyuk P. I., Volohovich V. A. and Moiseeva I. G., 1986. Elektroforeticheskij analiz belkov selskohozyajstvennoj pticy: metodicheskie rekomendacii. Harkov, 32.

10. Baker C., Croiser G. and Stratil A., 1970. Identity and nomenclature of some protein polymorphism of chicken eggs and serum. Advan. Genet., issue 5, no. 2. pp. 147-174.

11. Moiseeva I. G., Kutnyuk P. I. and Volohovich V. A. 1985. Geneticheskij analiz izmenchivosti belkov selskohozyajstvennoj pticy: metodicheskie rekomendacii. Harkov, 16. 
12. Podstryeshnij O. P., Nalivajko L. I. and Bondarenko Yu. V. Genetichnij polimorfizm v populyaciyah velikih sirih gusej. Ptahivnictvo. 2001. issue 50. pp. 19-26.

13. Smalec E. M., Miszkiewicz J. and Wojcik E., 2001. The protein polymorphism of different goose strains. Poultry breeding, issue 51 , pp. 141-145.

14. Sruoga A., Yanushonis S. and Butkauskas D. 2002. Geneticheskie markery v issledovanii differenciacii porod domashnih gusej. Veterinarija ir zootechnika, issue 20 (42), pp. 101-106.

15. Hvostik V. P. Dinamika genetichnoyi strukturi ptici pri stvorenni novih ta udoskonalenni isnuyuchih populyacij yayechnih kurej : avtoref. dis. ... kand. s.-g. nauk : 06.02.01. Harkiv, 2004. 20 s. Ukraine)

Bondarenko Yuriy Vasyleevich, Doctor of Biological Sciences, Professor, Sumy National Agrarian University (Sumy,

Khvostik Victor Pavlovich, Doctor of Agricultural Sciences, Institute of Animal Breeding and Genetics nd. a. M.V.Zubets of NAAS (Chubynske, Ukraine)

Genetic structure of ovoprotein loci in the process of creation of a dimorphic population of geese

The work was carried out in the breeding plant DPPP "Rozdolne" of Kharkov region for breeding geese of Large Gray and Rhine breeds. As a result of direct and reverse crossings of birds of these breeds, geese of dimorphic population with double autosexuality were bred at the age of one day and at one age. A study of the genetic structure of polymorphic loci of egg white geese of the original parental forms, descendants of the first and third generations and the created dimorphic population. After starch gel electrophoresis, the fractional composition of ovoproteins was divided into the following intensely colored zones: ovoalbumin (OV), ovomucoid (OM), transferrin (TF), ovomacroglobulin (OMG). In the experimental bird, the OV, TF, and OMG loci were found to be monomorphic - all individuals had a homozygous AA phenotype, so the frequency of the * $A$ allele in each of these loci was 1,000. Significant differences between the studied groups of geese were found at the locus of ovomucoid OM, which turned out to be strongly polymorphic and represented by a three-allele codominant system ${ }^{*} A,{ }^{*} B,{ }^{*} C$. The differences are primarily related to the nature of the distribution of phenotypes and the degree of coincidence of the actual and theoretically expected number. In all studied groups of birds, the basis of the population gene pool consisted mainly of carriers of the $O M^{*} A$ allele in the homo- or heterozygous state. In this case, less heterozygous individuals of $A B$ were actually detected, and homozygous $A A$ - more than theoretically expected. In the locus that determines the ovomucoid polymorphism, the frequency of the more common allele * $A$ in geese of the studied groups was in the range of 0.531-0.750. It should be noted that significant differences in the frequency of alleles in this locus between the geese of the studied populations were not achieved. According to the level of heterozygosity, no probable difference was found between the studied groups of birds. The lowest rate of heterozygosity was found in Large Gray geese (7.19\%), in the Rhine slightly more - 12.19\%. In geese of the first generation, the level of heterozygosity occupies an intermediate position (11.56\%) between the original parent breeds. In geese $F_{2}-F_{3}$ and dimorphic population, the level of heterozygosity increases to $13.75-15.00 \%$.

Key words: geese, crossbreeding, locus, egg white, genetic structure, heterozygosity.

Дата надходження до редакції: 12. 10.2020 р. 